\title{
The Effects of Dynamic Changes in Bank Competition on the Supply of Small Business Credit
}

\author{
Allen N. Berger \\ Board of Governors of the Federal Reserve System \\ Washington, DC 20551 U.S.A. \\ Wharton Financial Institutions Center \\ Philadelphia, PA 19104 U.S.A. \\ Lawrence G. Goldberg \\ Department of Finance, University of Miami \\ Coral Gables, FL 33124 U.S.A. \\ Lawrence J. White \\ Stern School of Business, New York University \\ New York, NY 10012-1126 U.S.A.
}

April 2001

\begin{abstract}
We study the effects of structural changes in banking markets on the supply of credit to small businesses. Specifically, we examine whether bank mergers and acquisitions (M\&As) and entry have "external" effects on small business loans by other banks in the same local markets. The results suggest modest positive external effects from these dynamic changes in competition, except that large banks may reduce small business lending in reaction to entry. We confirm bank size and age as important determinants of this lending, and show that the measured age effect does not appear to be driven by local market M\&A activity.
\end{abstract}

JEL Classification Numbers: G21, G28, G34, E58, L89

Keywords: Bank, Mergers, Small Business

The opinions expressed do not necessarily reflect those of the Board of Governors or its staff. The authors thank Simon Benninga, Ken Carow, Philipp Hartmann, Chris James, Julapa Jagtiani, and two anonymous referees for helpful comments and thank Seth Bonime, Kelly Bryant, and Nate Miller for outstanding research assistance.

Please address correspondence to Allen N. Berger, Mail Stop 153, Federal Reserve Board, 20th and C Sts. NW, Washington, DC 20551, call 202-452-2903, fax 202-452-5295, or email aberger@ frb.gov. 


\section{Introduction}

Structural changes in the banking industry have altered competitive relationships among market participants. There has been substantial merger and acquisition (M\&A) activity in response to the removal of regulatory restrictions, advances in information processing and communications technologies, financial engineering and other improvements in applied finance, and many other changes in market conditions. There have also been a large number of market entries of new banks, some of which appear to be in response to the M\&A activity in local banking markets.

To assess the full consequences of these changes in the competitive environment, it is necessary to determine the effects of these dynamic changes on the behavior of other market participants. In this paper, we measure the impact of M\&As and of entry on the supply of small business credit by other banks in the same local markets.

These issues have important policy implications, given the concern that recent developments in banking may reduce access to credit for the small business sector. A considerable amount of extant research suggests that the consolidation of the banking industry, particularly through M\&As that create large institutions, may substantially reduce small business lending by the M\&A participants.

However, a limited amount of recent research suggests that there may be "external effects" of dynamic changes in competition on the behavior of other market participants that may offset the actions of M\&A participants and change the policy conclusions. One finding is that there may be an external effect of M\&As in which other lenders in the same local markets expand their small business lending and make up for some of the reduced supply by the M\&A participants. Others have found a second external effect of M\&As - that they may affect the probability of market entry. A third result in this new literature is that recent entrants tend to lend much more to small businesses than do mature banks of similar size and other characteristics. One potential explanation for this extraordinary small business lending of recent entrants is that it may be part of an external effect of M\&As in their local markets, given that much of the entry took place following M\&As in their markets. This possibility has not been investigated, since there have been no prior studies to our knowledge of small business lending that 
accounted for both local market M\&As and bank age.

Further, there has been no research to our knowledge on the external effects of new entry on the behavior of incumbent banks in the market. New entrants could reduce the small business lending of incumbent banks by taking some of the market away from them, or alternatively could stimulate competition in the market. Additional research is needed to broaden and deepen the findings of the few studies of the external effects of bank M\&As, and to extend the literature to cover the potentially important external effects of entry on the small business lending of other banks in the market.

This paper addresses these issues. We model small business lending by banks as a function of market M\&A activity, entry, and other market and bank-specific factors, including the size and age of the bank. We estimate this model econometrically on U.S. bank data for the years 1993-1998. We also explore subsamples of these data classified by bank size and by age because prior research suggests that different sizes and ages of banks may be very differently affected by dynamic changes in bank competition. We also distinguish between bank mergers, in which two or more bank charters are consolidated, and bank acquisitions in which the banks retain their separate charters but change top-tier holding company ownership. As discussed below, these two types of changes in corporate governance may have different effects on the small business lending market.

Although our empirical application uses U.S. data, these issues addressed and implications of the findings are also quite important elsewhere, especially in Europe. The Single Market Programme in the European Union - particularly the Second Banking Co-ordination Directive of 1989 which introduced a single banking license valid throughout the EU - has considerably reduced the barriers to cross-border M\&As, and a number of institutions have taken advantage of this deregulation. Our research may give some qualitative information as to the likely external effects of such M\&A activity. In addition, cross-border consolidation is also a form of entry into another market, and so our results on the external effects of local market entry in the U.S. may give some clues as to which direction any external effects of cross-border entry might be elsewhere. The continuing implementation of the European Monetary Union may also be expected to increase cross-border 
consolidation in the participating nations by improving trade, by reducing currency conversion costs, and by lowering the costs to customers of purchasing services from foreign institutions.

The remainder of the paper is organized as follows. Section II reviews the relevant literature. Section III discusses the methodology and data employed in the analysis. Section IV presents the empirical results and Section V draws conclusions.

\section{Literature Review}

As noted above, there is a public policy concern that bank M\&As may result in a reduction in the supply of credit to small businesses. This may occur because the larger, more organizationally complex banks created by M\&As may encounter Williamson-type organizational diseconomies from serving relationship-based small business borrowers along with the large transactions-based customers typically served by large, complex banking organizations. The reduction in services to small customers may also result in part from the increased investment opportunities to serve large customers afforded by larger bank size, which "crowds out" small business loans in the use of increasingly costly funds. A reduction in services provided to small businesses might also result in part from short-term disruptions caused by the M\&A process, which gives other banks opportunities to "steal" customers who perceive a reduction in service quality or availability. The press often reports substantial customer runoffs after an M\&A.

Supporting these arguments, a number of studies have found that larger banks devote lesser proportions of their assets to small business lending than do smaller institutions (e.g., Berger, Kashyap, and Scalise 1995). Some evidence also suggests that it is specifically relationship-dependent small borrowers that tend to receive less credit from large banks. One study found that large banks tend to charge about 1 percentage point less on small businesses loans and require collateral about $25 \%$ less often than do small banks (Berger and Udell 1996). These data suggest that large banks tend to issue small business loans to higher-quality transactions-based credits, which tend to have lower rates and collateral requirements than riskier relationship-based loans. Similarly, one study found that the small business loans that are made by large banks tend to be to larger, older, more financially secure businesses, which are most likely to receive transactions-based credit (Haynes, Ou, and Berney 
1999). Finally, another study found that large banks tend to base their small business loan approval decisions more on financial ratios, whereas a prior relationship with the borrowing firm matters more to decisions by small banks, again consistent with large banks focusing on transactions-based credits and small banks focusing on relationship-based credits (Cole, Goldberg, and White 1999).

A number of studies directly examined the effects of bank M\&As on small business lending (e.g., Peek and Rosengren 1998, Strahan and Weston 1998, Berger, Saunders, Scalise, and Udell 1998, Avery and Samolyk 2000). The most common findings are that M\&As in which one or more of the banking organizations is large tend to reduce small business lending, whereas M\&As between small organizations tend to increase small business lending. Since M\&As involving large organizations dominate M\&As in terms of assets, these studies suggest an aggregate net reduction in small business lending by the banks participating in M\&As.

One previous study measured the external effects of M\&As on the small business lending of other banks in the market. It found expanded small business lending of other banks in the same local market that tended to offset much, if not all of the reductions in small business lending by the M\&A participants (Berger, Saunders, Scalise, and Udell 1998). A related study measured the total effects of M\&As on small business lending growth in local markets, but did not distinguish between the effects of the M\&As on the participating banks versus the external effects on other banks. It found that the total effects varied by nature of the market and the M\&A activity (Avery and Samolyk 2000).

Another set of studies identified a second possible external effect of M\&As - that they may affect the probability of market entry. If M\&As create larger banks that reduce their supply of relationshipbased credit to some small businesses, then new small banks may enter the market to supply these customers. One way that this might occur is that loan officers who leave the consolidated institution take some of their relationship-based loan portfolios with them and start a de novo bank. Two studies found evidence of this second external effect, providing evidence that M\&As increase the probability of entry into local markets (Berger, Bonime, Goldberg, and White 2000, Keeton 2000, although one study found that M\&As decrease the probability of entry (Seelig and Critchfield 1999). 
A few studies have found other evidence about the lending behavior of recent market entrants that may also reflect external effects of M\&As. These studies found that recent entrants tend to lend more to small businesses as a percentage of assets than do mature small banks, other things held equal, and that this difference tends to persist for as long as 20 years after entry (DeYoung 1998, Goldberg and White 1998, DeYoung, Goldberg, and White 1999). This finding could in part reflect external effects of M\&As, given that entrants tend to be in markets with high M\&A activity. However, these studies did not include bank M\&As as explanatory variables, so it is difficult to determine whether the unusually high lending of young banks is related to M\&A activity.

We are unaware of any prior research on the external effects of the other major dynamic change in bank competition - new market entry. As noted above, entry could be followed by either a reduction or an increase in the small business lending of incumbent banks in the market, depending on whether the incumbents cede some of the market to the new competitors or become more aggressive in trying to keep or expand their own market shares. Information on the external effects of entry may also shed light on the total effects of M\&As, given the finding that M\&As may change the probability of entry. As described in the next section, we try to extend the extant research by investigating the external effects of both M\&As and entry on small business lending, taking into account the effects of a bank's own consolidation activity, size, age, and many other factors.

\section{Methodology and Data}

We estimate the relationship between banks' small business lending and the influences on those banks by modeling each bank's small business lending as a ratio to that bank's total assets: $(\mathrm{SBL} / \mathrm{GTA})_{\mathrm{i}, \mathrm{m}, \mathrm{t}}$, where $\mathrm{i}$ indexes the bank, $\mathrm{m}$ indexes the bank's market, and $\mathrm{t}$ indexes the year. This ratio is then converted into the form of a log-odds ratio: $\ln \left((\text { SBL/GTA })_{i, m, t} t\left(1-(\text { SBL/GTA })_{i, m, t}\right)\right)$. The log-odds ratio has the natural interpretation of a grouped logistic form in which the bank chooses to allocate each dollar of gross total assets between small business loans and other investments. The use of the log-odds form in place of the simple lending ratio (SBL/GTA) $)_{i, m, t}$ also reduces problems associated with the use of a fraction that is often close to the limiting value of zero in a least-squares 
estimation. ${ }^{1}$ We estimate the following regression:

$\ln \left((\mathrm{SBL} / \mathrm{GTA})_{\mathrm{i}, \mathrm{m}, \mathrm{t}} /\left(1-(\mathrm{SBL} / \mathrm{GTA})_{\mathrm{i}, \mathrm{m}, \mathrm{t}}\right)\right)=\mathrm{f}\left(\mathrm{MARKET} \mathrm{M}_{\mathrm{i}} \mathrm{A}_{\mathrm{i}, \mathrm{m}, \mathrm{t}-1, \mathrm{t}-\mathrm{t}, \mathrm{t}-3}, \mathrm{MARKET} \mathrm{ENTRY}_{\mathrm{i}, \mathrm{m}, \mathrm{t}-\mathrm{t}, \mathrm{t}-\mathrm{t}, \mathrm{t}-3}\right.$,

OTHER COMPETITIVE MARKET CONDITIONS C $_{\mathrm{i}, \mathrm{m}, \mathrm{t}-1}$, MARKET DEMAND CONDITIONS $_{\mathrm{i}, \mathrm{m}, \mathrm{t}-1}$, MARKET PRICES $_{\mathrm{i}, \mathrm{m}, \mathrm{t}-1}$, CONDITION OF MARKET BANKS $_{\mathrm{i}, \mathrm{m}, \mathrm{t}-1}$, BANK AGE $\mathrm{i}_{\mathrm{t}, \mathrm{-}-1}, \mathrm{BANK}$ M\&A $\mathrm{A}_{\mathrm{i}, \mathrm{t}-1, \mathrm{t}-2, \mathrm{t}-\mathrm{3},}$ BANK SIZE AND SHARE $\mathrm{i}_{\mathrm{i}, \mathrm{t}-1}, \mathrm{BANK}$ OWNERSHIP STRUCTURE AND ORGANIZATIONAL COMPLEXITY ${ }_{\mathrm{i}, \mathrm{t}-1}$, BANK CONDITION COI,-1 $_{\text {, }}$ ANNUAL DUMMY VARIABLES $\left.\mathrm{t}_{\mathrm{t}}\right)+\mathrm{e}_{\mathrm{i}, \mathrm{t}}$

This equation is estimated py weighted least squares to avoid heteroskedasticity problems, and the adjusted $\mathrm{R}^{2} \mathrm{~s}$ are corrected. ${ }^{2}$

Table 1 presents the definitions, means, and standard deviations for all of the variables over the time period 1993-1998 for small banks (GTA up to \$100 million) and for large banks (GTA above $\$ 100$ million). As of year-end 1998, 62\% of banks were in the small bank sample, but the large bank sample controlled about $95 \%$ of the nation's assets. Virtually all financial variables are measured in real 1994 terms, usually in thousands of 1994 dollars. One exception is that small business loans are defined as commercial and industrial loans to borrowers with bank credit less than $\$ 1$ million in nominal terms that has been reported annually for all U.S. banks each June, starting in 1993 . $^{3}$

\footnotetext{
${ }^{1}$ In the few cases in which SBL/GTA was zero or very close to it, we substituted the value 0.0001 , so as to avoid having the dependent variable be at or close to $-\infty$. There were no observations where SBL/GTA was at or near to 1.0, so no adjustments were necessary at the upper end of the distribution.

${ }^{2}$ To correct for heteroskedasticity, each observation is divided by a number that is proportional to the estimated standard error of its error term, or $\left[\left\{\left(1 /(\mathrm{SBL} / \mathrm{GTA})_{\mathrm{i}, \mathrm{m}, \mathrm{t}}\right)+\left(1 /\left[1-(\mathrm{SBL} / \mathrm{GTA})_{\mathrm{i}, \mathrm{m}, \mathrm{t}}\right]\right)\right\} / \mathrm{GTA}_{\mathrm{i}, \mathrm{m}, \mathrm{t}}\right]^{1 / 2}$. In effect, within a sample, larger banks and banks with proportions of small business loans closer to 1 or 0 are weighted more heavily, since these observations provide more information about the probability that $\$ 1$ of GTA will be allocated to small business lending.

${ }^{3}$ Since this credit limit of $\$ 1$ million is not adjusted for inflation, it is a slightly smaller real cutoff each successive year, and we have no means to correct this. However, we deflate the quantities of measured small business lending and all other value variables in the analysis to put them in real 1994 dollars. Following prior research using the definitions in the June Call Reports, we measure the credit limit of the borrower as the maximum of 1) the size of the loan from the bank, 2) the total commitment under which the loan was drawn (if any), and 3) the total size of the participation by all banks in a participation (if any).
} 
We estimate the small business lending models separately for small and large banks in part because of the important differences in small business lending of small and large banks found in the literature. As discussed above, large banks tend to devote lesser proportions of their assets to small business lending than do small banks. The small business loans that large banks do grant appear to be more often transactions-based credits than relationship-based loans. Therefore, we expect and wish to allow for the possibility that small and large banks will have different reactions to dynamic changes in competition in their markets. In addition, large banks typically have very different lending opportunities than small banks. A bank with assets below $\$ 100$ million generally cannot make any business loans other than small business loans because of legal lending limits and problems of diversification. For example, a bank with $\$ 100$ million in assets and a $6 \%$ equity capital ratio cannot have total credit exposure to a single borrower of over $\$ 900,000$ ( $15 \%$ of equity) under legal lending limits, and so cannot make loans greater than $\$ 1$ million, the cutoff for defining small business loans in the Call Report and in most of the research on small business lending in the U.S. In addition, M\&As involving large banks were found to have different effects on their own lending than M\&As involving only small banks, so different reactions to the M\&As of other banks might be expected as well. Importantly, large banks tend to be more often involved in M\&A activity and de novo entrants tend to be small, so we might expect large banks to be more often the direct competitors of banks engaging in M\&A activity, and small banks to be more often the direct competitors of new entrants. In addition, prior research found an especially strong effect of bank age on the small business lending of small banks that we wish to investigate further by separating small and large banks. Our empirical results below confirm some important differences in findings for large and small banks in terms of the effects on their lending of market entry, age, and other variables, supporting our decision to run separate regressions and suggesting that pooling the data would not be appropriate. We also run the small bank sample separately by age group and confirm the prior finding of very different propensities to lend of young versus mature small banks.

Although the SBL/GTA ratios of the small and large bank samples shown in Table 1 are similar, 
the large bank sample encompasses considerable variation, as can be seen from the mean SBL/GTA ratios for the following size groupings:

Small banks (GTA $\leq \$ 100 \mathrm{M}): 0.0849$

"Somewhat large" banks ( $\$ 100 \mathrm{M}<\mathrm{GTA} \leq \$ 1 \mathrm{~B})$ : 0.0840

"Fairly large" banks $(\$ 1 \mathrm{~B}<\mathrm{GTA} \leq \$ 10 \mathrm{~B})$ : 0.0494

"Very large" banks (\$10B<GTA): 0.0295

These ratios confirm the findings of previous studies that larger banks tend to devote smaller proportions of their assets to small business lending. These size groupings for the larger banks are captured by dummy variables in our regression analysis of the larger banks. We also tried running separate regressions for the "somewhat large," "fairly large," and "very large" subsamples of large banks (not shown). The results were qualitatively consistent with the results shown for all large banks together, but the results for the finer subsamples were generally not statistically significant because of the small numbers of observations relative to the numbers of explanatory variables. For our main results, we use the $\$ 100$ million cutoff between large and small banks because 1) $\$ 100$ million is the cutoff found in the literature to create most of the important differences in lending between large and small banks, 2) it is approximately the size at which legal lending limits restrict a bank to make only small business loans of $\$ 1$ million or less, 3) smaller groupings of large banks have too few observations to obtain statistically significant results, and 4) the \$100 million cutoff "works" - we find economically and statistically significant differences in lending between banks over and under this cutoff.

The data are annual. The dependent variable is based on the allocation of assets as of the end of June of year $t, t=1993, \ldots, 1998$. All of the right-hand-side variables are measured as of the end of year t-1 or earlier to reduce endogenous feedback effects. Most of the exogenous variables are based on either the market(s) in which the bank operates or on the characteristics of the bank itself. For a bank that is present in more than one market, we use a weighted average over all the markets in which the bank operates for the market-level variables, where the weights are the proportions of the bank's 
deposits in each market. To distinguish between the market-level and bank-level variables, we generally use the prefix "WAM" (for weighted average market) to signify the former and the prefix "BANK" to signify the latter.

As noted above, we distinguish between two main types of consolidation, mergers and acquisitions. We allow for different effects of bank mergers in which two or more bank charters are consolidated (denoted by the suffix "MERGE"), versus bank acquisitions in which banks retain their separate charters, but become owned by a new or different top-tier bank holding company (denoted by the suffix "ACQUIS"). Mergers may be more disruptive to a banking organization because they often involves replacement of the senior managers and board of directors of one of the banks, changes in policies and procedures, and integration of financial and accounting systems. In an acquisition, the organizational changes may often be much less, and the bank may be strengthened by having more resources upon which to draw. Consequently, mergers may provide greater opportunities for the expansion of small business lending by other banks in the affected markets than acquisitions. The literature has also found different effects of mergers versus acquisitions on small business lending (e.g., Berger, Saunders, Scalise, and Udell 1998).

We measure past M\&As at both the market level (WAM-MERGE and WAM-ACQUIS) and the bank level (BANK-MERGE and BANK-ACQUIS). We include three past years of M\&As because prior analyses of bank M\&As and reports by bank consultants suggest that at least three years are needed to complete any restructuring or refocusing of a bank after an M\&A (e.g., Toevs 1992); the external effect on other banks in the local market may well take about as long. Similarly, we include three past years of entry (WAM-ENTRY), because it takes time for a de novo bank to acquire deposits and acquire loan customers and the external effect on other banks may be as long. ${ }^{4}$

The bank balance sheet and income data come primarily from the bank Call Reports. Structural

\footnotetext{
${ }^{4}$ Following a referee's suggestion, we express the entry variable as a weighted average of a dummy variable for whether entry occurs in a bank's markets. Because the relative influence of entry may be dependent on the overall size of the market, as a robustness test we also expressed entry as the number of entrants per $\$ 100$ million of deposits in a bank's markets, with little difference in the economic significance of the results.
} 
information is also gathered from the National Information Center (NIC), and the information on the location and total deposits of every bank branch is taken from the FDIC Summary of Deposits files. These data are also supplemented from other sources, such as census data (state income growth) and regulatory data (state branching restrictions).

With respect to the other exogenous variables in equation (1) and shown in Table 1, the marketlevel variables are grouped into four major categories: other competitive conditions in the bank's market(s); demand conditions in the bank's market(s); prices in the bank's market(s); and the conditions of other banks in the bank's market(s). Variables that are indicative of greater market profitability are expected to have positive effects on a bank's small business lending. The bank-level variables are grouped into five categories: the bank's age; the bank's M\&As; the bank's size and market share; the bank's ownership structure and organizational complexity; and the bank's financial condition. Notably, the bank size variables include the natural log of bank assets (BANK-LNGTA), as well as dummies for all but one size class within the ranges of both small and large banks. As discussed above, there are substantial differences in small business lending propensities across the size classes of large banks. Since the prior literature has shown that (for small banks) a bank's age is negatively related to a bank's lending, we expect to find that relationship as well, at least for our small bank sample. Further, the complexity of a bank's holding company structure may influence its small business lending, as may its own recent M\&A history and a weakened financial condition. Finally, to control for specific year effects, we include annual dummy variables for the years 19941998 (1993 is treated as the base case).

In Table 2, we provide additional details on four important exogenous variables: WAM-MERGE (the weighted average of mergers in a bank's markets); WAM-ACQUIS (the weighted average of acquisitions in a bank's markets); WAM-ENTRY (the weighted average of the occurrence of entry in a bank's markets); and GTA (the bank's gross total assets). As shown in Panel A, all of these variables have skewed distributions for both the small-bank and large-bank subsamples. Substantial proportions of the markets have no dynamic changes in competition measured by WAM-MERGE, WAM- 
ACQUIS, and WAM-ENTRY, particularly the markets in which small banks are present. For example, in over $75 \%$ of the bank-year observations for small banks, and over $50 \%$ of the observations for large banks, there was no market entry over the prior three years. The skewed distributions of bank size, particularly for large banks, is well known. The largest bank, at over $\$ 278$ billion in GTA, is more than 1,000 times as large as the median large bank, which has GTA just under \$200 million. In Panel B, we see that the increased rate of consolidation over time is primarily concentrated in mergers (WAMMERGE), as opposed to acquisitions (WAM-ACQUIS). The shares of market deposits in banks involved in mergers over the previous three years grew monotonically and almost doubled over the 1993-1998 time period from $7.88 \%$ to $14.85 \%$ for small banks and from $12.63 \%$ to $24.12 \%$ for large banks. In contrast, acquisitions and entry (WAM-ENTRY) do not have monotonic growth paths. The mean bank size (GTA) grew by almost $40 \%$ over the sample period for large banks, primarily due to mergers. The small bank mean GTA remained approximately constant over time, as entry provided additional very small banks and mergers pushed some of the largest small banks into the large-bank subsample.

\section{Empirical Results}

\section{A. Small Bank Results}

We first analyze the effects of dynamic changes in bank competition on the small business lending of small banks. The first column of Table 3 shows the small business lending regressions for 19931998 for all small banks. Beginning with the market M\&A variables, we argued above that the effects of bank mergers may differ from those of bank acquisitions. The coefficients on WAM-MERGE and WAM-ACQUIS in Table 3 support this argument. The external effect on banks' small business lending of bank mergers in their markets (WAM-MERGE) is positive and statistically significant at the $1 \%$ level (two-sided) for the small bank sample. By contrast, the coefficient on WAM-ACQUIS is negative, but not statistically significant. In part, the difference in measured effects of mergers and acquisitions may reflect collinearity between these variables - these dynamic changes in competition tend to occur together in large metropolitan markets. 
In addition to assessing the size and statistical significance of the individual coefficients, it is important to evaluate the economic significance of these changes in banking market structure on small business lending. We evaluate the economic significance of mergers and acquisitions together, since they are two parts of the same consolidation process and because the two variables are highly collinear. We ask the question, "What is the total quantitative effect of M\&As of banks in the local market on the small business lending of the average small bank?"

One useful way to answer this question is to simulate the effects of the presence of the average level of market M\&As, as compared with their complete absence, on the mean proportion of small business lending by small banks. Starting from the mean value of 0.0849 for SBL/GTA, we simulate the effect on SBL/GTA of moving the M\&A variables from their own mean values of 0.1148 for WAM-MERGE and 0.0299 for WAM-ACQUIS to zero (mean values are shown in Table 1). Based on the coefficients shpwn in the first column of Table 3, this would give a predicted value for SBL/GTA of $0.0836 .^{5}$ Thus, eliminating market M\&As is predicted to move the small business lending ratio from $8.49 \%$ to $8.36 \%$, a decrease of 0.13 percentage points or about $1.53 \%$. This percentage increase is somewhat smaller than the external effect of $3.6 \%$ found by Berger, Saunders, Scalise, and Udell (1998) using a different set of other variables and a different data set.

Turning to the effects of market entry, we find that the coefficient on WAM-ENTRY is positive and statistically significantly different from zero. Thus, it appears that the net effect of entry is to stimulate, rather than to take away, small business lending by other small banks on average. This result is perhaps not surprising, given that small banks often tend to specialize in small business lending, and so may put more resources into this service when threatened with new competition. It is likely that entry reduces small business lending by other banks in some markets, but this is offset by increased

\footnotetext{
${ }^{5} \mathrm{We}$ arrive at this estimate as follows: We begin with the mean SBL/GTA ratio of 0.0849 and calculate the logodds ratio; we then subtract the mean value of WAM-MERGE (from Table 1) times its coefficient in Table 3 and subtract the mean value of WAM-ACQUIS times its coefficient. We then convert this new log-odds ratio to a new SBL/GTA ratio. Thus, we find SBL/GTA $=0.0836$ by calculating: $\ln (\mathrm{SBL} / \mathrm{GTA}) /(1-(\mathrm{SBL} / \mathrm{GTA}))=$ $\ln (0.0849 /(1-0.0849))-(0.1772 \cdot 0.1148)-(-0.1883 \cdot 0.0299)$.
} 
lending by incumbents in other markets with entry. The overall economic effect, however, is quite modest. Using the same simulation methodology as just described, the model predicts that eliminating market entry would move the SBL/GTA ratio from $8.49 \%$ to $8.43 \%$. This small measured external effect of market entry is driven in part by evaluating at the low mean level of market entry that was experienced by these small banks in their markets, 0.1162. As an alternative way to measure the economic effect of entry on small business lending, consider the effect on a small bank of starting from zero entry (setting WAM-ENTRY $=0$ and using the predicted value of SBL/GTA=8.43\%) to experiencing an average of 1 entry per year in all of its markets (WAM-ENTRY = 1), the bank's SBL/GTA percentage would have risen to $8.89 \%$-- an increase of 0.46 percentage points, or $5.46 \%$. There are no benchmarks against which to compare these findings, as these are the first estimates of the external effect of market entry.

As noted above, a result in the literature is that recent entrants tend to lend much more to small businesses than do mature banks of similar size and other characteristics for up to 20 years. This may reflect in part an external effect of market M\&As, given that much of the entry took place following M\&As in their markets. The effect of bank age in the small bank regression may help address this issue, as it controls for market M\&As, something not done in the prior analyses. Bank age (BANKLNAGE) has a large negative coefficient, consistent with prior research. Reinforcing this general negative effect of age, the dummy variables for BANK-ADOLES and BANK-MATURE have significant negative coefficients (BANK-YOUNG is the omitted category), indicating that the decline of small business lending with a bank's age is even steeper than the relationship indicated by the BANK-LNAGE variable alone. The effect of bank age is quite strong in terms of economic significance. The difference between the predicted mean SBL/GTA for young small banks (average age $=2.60$ years) and for mature small banks (average age $=77.01$ years) is a decrease from $13.00 \%$ to $7.72 \%$, a decline of 5.28 percentage points or $40.62 \%$. $^{6}$ Since market M\&As are controlled for in this

\footnotetext{
${ }^{6}$ These calculations are performed similarly to the simulations described above. For example, to calculate SBL/GTA for young banks, we start at the mean and then simulate a change in BANK-LNAGE variable from its mean (3.8411) to its mean for young banks (1.2228), and changes in BANK-ADOLES and BANK-
} 
regression, these findings suggest that the extraordinary lending of young and adolescent banks exists for reasons other than market M\&As, although we cannot rule out some effect of the market M\&As.

We investigate the bank age issue further in the final 3 columns of Table 3. These provide regression results for "young" (ages 1-5) small banks, "adolescent" (ages 6-20) small banks, and "mature" (21+ years) small banks. As can be seen, the results for young small banks do not yield significant external effects of market M\&As nor of market entry. For adolescent small banks, there is a significant positive external effect from market mergers (WAM-MERGE), although market acquisitions (WAM-ACQUIS) and market entry (WAM-ENTRY) have no significant effect on adolescents. Finally, for mature small banks, there is a significant positive external effect from market mergers (WAM-MERGE) but a negative and significant effect of market acquisitions (WAMACQUIS). The external effect of market entry (WAM-ENTRY) is positive and significant. These results again suggest that an external effect from market M\&As is not the driving force behind the focus on small business lending by recent market entrants.

We briefly discuss some of the results that pertain to the remaining explanatory variables. With respect to competitive conditions in banking markets, the coefficient on the Herfindahl index (WAMHERF) is positive. This is consistent with the literature that suggests that relationship lending may increase when lenders have more market power because these lenders can enforce long-term implicit contracts in which the borrower receives a subsidized interest rate in the short term, and compensates the bank by paying a higher-than-competitive rate in a later period (Sharpe 1990, Petersen and Rajan 1995). The coefficients on the shares of large banks (WAM-SHAREL) and complex banks (WAMSHAREC) are negative, contrary to the expectation that markets with more large and complex banks would yield more small business lending opportunities for the smaller banks of this sample. The coefficient on a bank's presence in a metropolitan area (BANK-INMSA) is negative, which may reflect greater competition for small business customers in metropolitan markets.

With respect to demand conditions in banks' markets, state income growth (STINCGROW) and

MATURE from their means ( 0.1734 and 0.7868 , respectively) to 0 . 
local market growth (WAM-GROW) are insignificant, possibly in part because of collinearity, since market growth and state growth generally go hand-in-hand. It is also possible that state and local economic strength is associated with more lending to larger firms, and to a migration of small firms into the large-firm category (i.e., into more than $\$ 1$ million in bank debt). The size of the market (WAM-LNDEP) is positive and statistically significant. With respect to market prices, the results are mixed. As for the condition of banks in the market, greater profitability (WAM-ROE) has a positive coefficient, as expected.

The effects of a bank's own M\&As on its own small business lending involve the coefficients on BANK-MERGE, BANK-ACQUIS, the bank size variables [BANK-LNGTA, BANK-SZU10M, BANK-SZ10M25M, and BANK-SZ25M50M (the largest small-bank size BANK-SZ50M100M is excluded as the base case)], and BANK-SHARE. The coefficients on BANK-MERGE and BANKACQUIS are statistically insignificant. The coefficient on BANK-LNGTA is negative and significant, but the coefficients on the smaller size-class dummy variables are negative, which tends to offset the effect of BANK-LNGTA. The coefficient on BANK-SHARE is negative and significant. Thus, the effects of bank M\&As on own small business lending are mixed. If two relatively small banks of up to about \$20 million in GTA each were to merge, the net effect on small business lending would generally be positive, especially if their market shares were small or the merger was out-of-market and postmerger share was not appreciably different from the pre-merger shares. But mergers among larger banks within the "small" category would tend to decrease small business lending. These results are generally consistent with the literature, which found that M\&As among the smallest banks increased small business lending, but the results were reversed for M\&As involving larger banks.

The membership of a bank in either a one-bank or a multi-bank holding company (BANKONEBHC and BANK-MBHC, respectively) has a positive effect on small business lending. If a bank is part of a multilayer holding company (BANK-MUL_LAY) or is a member of an out-of-state holding company (BANK-OUTST), then its small business lending tends to be reduced. Finally, a bank with a higher equity ratio (BANK-EQRAT) tends to do less small business lending. 


\section{B. Large Bank Results}

We now turn our attention to the SBL/GTA regressions for large banks, shown in the second column of Table 3 . The explanatory variables are the same as in the small bank regressions, except that we include only the continuous variable for bank age (i.e., we drop BANK-ADOLES and BANKMATURE), and we specify a different set of dummies for bank size classes [BANK-SZ100M1B and BANK-SZ1B10B, (the largest large-bank size BANK-SZG10B is excluded as the base case)].

The results for these large banks are broadly consistent with previous results for small banks. The coefficients on the WAM-MERGE and WAM-ACQUIS are similar in sign and magnitude to those for small banks, and again the former is significant. The coefficient on WAM-ENTRY is, however, negative and statistically significant, suggesting that on net, large banks tend to cede small business lending to new entrants, rather than being stimulated to compete against them. Perhaps this is not surprising, given that small business lending is generally not the main focus of large banks. Again, these effects reflect averages across markets that may have very different outcomes.

To examine the economic significance of the market M\&A and entry variables, we again start at the sample mean value of SBL/GTA (7.94\%) and simulate moving the values of market M\&As and entry from their mean values to zero. In the absence of market M\&As, the predicted SBL/GTA ratio would have been $7.77 \%$, a reduction of 0.17 percentage points, or $2.14 \%$. This decrease is slightly greater in magnitude than was found for small banks, and is again smaller than the effect found by Berger, Saunders, Scalise, and Udell (1998). In the absence of entry, the SBL/GTA ratio is predicted to be $8.14 \%$, so the absence of entry would predict an increase of 0.20 percentage points or $2.52 \%$. If instead we begin at the estimated average SBL/GTA ratio for the absence of entry (8.14\%) and move WAM-ENTRY from 0 to1 (i.e., from no entry to 1 entry per year in all of its markets), the predicted SBL/GTA ratio moves to $7.33 \%$, a decrease of 0.81 percentage points or a $9.95 \%$ decline.

There are a few more results of interest in the large-bank regression. First, unlike small banks, age (BANK-LNAGE) had a modest positive effect on large banks' small business lending, so the finding of strong negative effects of age is primarily concentrated on the small banks. To investigate this issue 
further, we reran the large bank regressions by size class (not shown in tables). In the subsample of "somewhat large" banks (GTA between $\$ 100$ million and $\$ 1$ billion), we found a strong significant negative relationship between age and small business lending, similar to the findings for small banks. However, for the larger size classes of banks with over \$1 billion in GTA ("fairly large" and "very large"), we found the opposite effect - a significant positive effect of age on small business lending.

With respect to competitive conditions, higher market concentration (WAM-HERF) had an even greater positive effect on lending than was true for small banks. State income growth (STINCGROW) had a negative effect on small business lending by large banks. As discussed above, this could in part reflect an increased emphasis on lending to large firms or a migration of small firms into the large-firm category. Again, larger markets (WAM-LNDEP) are associated with greater small business lending.

The effect of a bank's own M\&As on its small business lending is again the result of the coefficients on BANK-MERGE, BANK-ACQUIS, the size variables (BANK-LNGTA, BANKSZ100M1B, BANK-SZ1B10B), and BANK-SHARE. The coefficients on BANK-MERGE and BANK-ACQUIS are both positive; the former is sizable and significant. But the negative effects of greater size and larger share dominate, so that most mergers among large banks are expected to yield lower levels of small business lending, consistent with the prior literature.

The coefficients on the market prices of output substitutes and of inputs show a generally sensible set of signs: for example, higher returns on non-consumer loans (except real estate) (WAM-P2) causes large banks' small business lending to decline, as do higher returns on securities (WAM-P4). Finally, a large bank's small business lending is negatively affected by high rates of non-performing loans in the market (WAM-NPL) and is positively affected by market profitability (WAM-ROE) and by the bank's own equity ratio (BANK-EQRAT).

In sum, the results for large banks are broadly consistent with the results for small banks. The magnitudes of the external effects of M\&As are similar, and the general responses of banks to their market environments and to their own characteristics are largely sensible. For large banks, however, entry yields a negative external effect, while for small banks the external effect of entry is positive. 


\section{Conclusions}

Structural changes in the competitive environment for commercial banks have elicited concern about the supply of funds to small businesses. This study examines the effects of mergers and acquisitions (M\&As) and market entry on small business lending by banks, focusing particularly on the "external" effects of these changes on the behavior of other participants in the same local markets. Our data set is for U.S. banks over the time period 1993-1998, but the implications are also quite important elsewhere, especially in Europe where regulatory and market changes are making cross-border and within-nation M\&As and entry more frequent. We model the ratio of a bank's small business loans to its gross total assets as a function of market M\&As, market entry, its own M\&A activity, size, and age, and a number of control variables, and the results provide several important findings.

First, we find modest external effects of M\&As on the small business lending of both small and large banks in the same market. This finding is consistent with the one prior research study that measured the external effects of bank M\&As, but extends the prior finding by examining large and small banks separately, by accounting for the important effects of bank age and market entry, and by using more recent data.

Second, we find a small positive external effect of new bank entry on the small business lending of other small banks in the market. While new entrants may take some customers away from incumbent small banks, it appears that the entry also stimulates new competition in some markets and encourages small incumbents to increase their supplies to more than offset their lost business.

Third, we find a negative external effect of market entry on the small business lending of large banks. This finding suggests that on net, large banks tend to cede market shares of small business lending to new entrants, rather than being stimulated to compete against them. This is consistent with the focus of some large banks on competing for large corporate customers, rather than small business customers. To our knowledge, there has been no prior research on the external effects of entry on the behavior of either small or large banks, so there is no benchmark against which to compare our second and third main results. 
Fourth, we find very strong effects of bank age on small banks' small business lending. Consistent with prior research, we find that recent entrants tend to have much greater small business lending than do other banks of comparable size and other characteristics. This may reflect in part an external effect of market M\&As, given that much of the entry took place following local market M\&As, but prior research was unable to address this issue because no prior studies of small business lending to our knowledge accounted for both local market M\&As and bank age. Our evidence suggests that an external effect from market M\&As is not the driving force behind the negative association between age and small business lending for small banks. We find a strong effect of age after controlling for market M\&As in our main regression, and additional regressions by age group suggest that external effect of M\&As on small business lending is not concentrated on the youngest banks.

The findings in this paper also suggest some potential directions for future research. First, more research is needed to flesh out the nature and extent of the external effects of dynamic changes in competition. There is only one other study to our knowledge that measures the external effects of M\&As on small business lending of other banks in the market, and ours is the only study that measures the external effects of market entry. Our findings that M\&As and entry both appear to stimulate competition for small business lending by small banks, and M\&As but not entry appear to stimulate such market competition by large banks need to be confirmed or contradicted. In addition, future research may be able to resolve the unexplained phenomenon of the strong inverse relationship between bank age and small business lending for small banks, given our finding that this result could not be tied to market M\&As. The research on the external effects of dynamic changes in competition should also be extended to other nations to see if the results are robust. This may be of particular importance in Europe, given the regulatory changes that favor bank consolidation and cross-border entry. The research should also be extended to additional time periods and to different economic conditions. Although we have many observations in our data set, they are based on a relatively short time horizon and an unusually healthy period for U.S. banks, and so may not be broadly representative.

Importantly, our research and prior research on external effects has focused only on small business 
lending by banks. More research is needed on how the effects of dynamic changes in competition affect the prices, quantities, and quality of the entire range of banking services. Finally, the research on external effects could be extended beyond the banking industry as well - the concept of external effects may be applied to M\&As, entry, or other dynamic changes in competition in any industry to measure the total effects of these changes. 


\section{REFERENCES}

Avery, R.B., and Samolyk, K.A., 2000, Bank consolidation and the provision of banking services: The case of small commercial loans, Federal Deposit Insurance Corporation Working Paper.

Berger, A.N., Bonime, S.D., Goldberg, L.G., White, L.J., 2000, The dynamics of market entry: The effects of mergers and acquisitions on de novo entry and small business lending in the banking industry, working paper, Board of Governors of the Federal Reserve System.

Berger, A.N., Kashyap, A.K., Scalise, J.M., 1995, The transformation of the U.S. banking industry: What a long, strange trip it's been, Brookings Papers on Economic Activity (2), 55-218.

Berger, A.N., Saunders, A., Scalise, J.M., Udell, G.F., 1998, The effects of bank mergers and acquisitions on small business lending, Journal of Financial Economics 50, 187-229.

Berger, A.N., Udell, G.F., 1996, Universal banking and the future of small business lending. In: Saunders, A., Walter, I. (Eds.), Financial system design: The case for universal banking, Irwin, Burr Ridge, IL, 559-627.

Cole, R.A., Goldberg, L.G., White, L.J., 1999, Cookie-cutter versus character: The micro structure of small business lending by large and small banks, in Business Access to Capital and Credit, edited by Jackson L. Blanton, Alicia Williams, and Sherrie L.W. Rhine, A Federal Reserve System Research Conference, 362-389.

DeYoung, R., 1998, Comment on Goldberg and White, Journal of Banking and Finance 22, 868-872.

DeYoung, R., Goldberg, L.G., White, L.J., 1998, Youth, adolescence, and maturity of banks: Credit availability to small business in an era of banking consolidation, Journal of Banking and Finance 23, 463-492.

Goldberg, L.G., White, L.J., 1998, De novo banks and lending to small businesses, Journal of Banking and Finance 22, 851-867.

Haynes, G.W., Ou, C., Berney, R., 1999. Small business borrowing from large and small banks, in Business Access to Capital and Credit, edited by Jackson L. Blanton, Alicia Williams, and Sherrie L.W. Rhine, A Federal Reserve System Research Conference, 287-327.

Keeton, W.R., 1997, The effects of mergers on farm and business lending at small banks: New evidence from Tenth District States," working paper, Federal Reserve Bank of Kansas City.

Keeton, W.R., 2000, Are mergers responsible for the surge in new bank charters? Federal Reserve Bank of Kansas City Economic Review 85 (1), 21-41.

Peek, J, and E.S. Rosengren, 1998, Bank consolidation and small business lending: It's not just bank 
size that matters, Journal of Banking and Finance 22, 799-819.

Petersen, M.A., Rajan, R.G., 1995, The effect of credit market competition on lending relationships, Quarterly Journal of Economics 110, 407-443.

Seelig, S.A., Critchfield, T., 1999, Determinants of de novo entry in banking, Federal Deposit Insurance Corporation Working Paper 99-1.

Sharpe, S.A., 1990, Asymmetric information, bank lending, and implicit contracts: A stylized model of customer relationships, Journal of Finance, 45, 1069-1087.

Strahan, P.E., Weston, J., 1998, Small business lending and the changing structure of the banking industry, Journal of Banking and Finance 22, 821-845.

Toevs, A., 1992, Under what circumstances do bank mergers improve efficiency? Proceedings of a Conference on Bank Structure and Competition, Federal Reserve Bank of Chicago, Chicago, IL, 602-628.

Whalen, G., 1995, Out-of-state holding company affiliation and small business lending, Office of the Comptroller of the Currency, Economic and Policy Analysis working paper 95-4. 
TABLE 1: Variables Employed in Small Business Lending Regressions for Small and Large Banks, 1993-1998

\begin{tabular}{|c|c|c|c|}
\hline Symbol & Definition & $\begin{array}{l}\text { Sm. Bank } \\
\text { Mean } \\
\text { (Std. Dev.) }\end{array}$ & $\begin{array}{l}\text { Lg. Bank } \\
\text { Mean } \\
\text { (Std. Dev.) }\end{array}$ \\
\hline & Dependent Variable & & \\
\hline SBL/GTA & $\begin{array}{l}\text { Small business loans (C\&I loans }<\$ 1 \text { million) as a proportion } \\
\text { of the bank's gross total assets (not included in regressions). }\end{array}$ & $\begin{array}{l}0.0849 \\
(0.0624)\end{array}$ & $\begin{array}{l}0.0794 \\
(0.0567)\end{array}$ \\
\hline \multirow[t]{2}{*}{$\begin{array}{l}\text { LN((SBL/GTA)/(1- } \\
(\text { SBL/GTA })))\end{array}$} & Log-odds ratio of SBL/GTA & $\begin{array}{l}-2.6671 \\
(0.9375)\end{array}$ & $\begin{array}{l}-2.7938 \\
(1.1061)\end{array}$ \\
\hline & $\begin{array}{l}\text { Mergers and Acquisitions (M\&As) and Entry in the } \\
\text { Bank's Market(s) }\end{array}$ & & \\
\hline WAM-MERGE & $\begin{array}{l}\text { Weighted average of the shares of market deposits in banks } \\
\text { involved in mergers (in which two or more bank charters are } \\
\text { consolidated, averaged over the previous three years), where } \\
\text { the weights are the proportions of this bank's deposits in each } \\
\text { market. }\end{array}$ & $\begin{array}{l}0.1148 \\
(0.1282)\end{array}$ & $\begin{array}{l}0.1774 \\
(0.1304)\end{array}$ \\
\hline WAM-ACQUIS & $\begin{array}{l}\text { Weighted average of the shares of market deposits in banks } \\
\text { involved in acquisitions (in which the banks retain their } \\
\text { separate charters but change their bank holding company } \\
\text { ownership, averaged over the previous three years), where the } \\
\text { weights are the proportions of this bank's deposits in each } \\
\text { market. }\end{array}$ & $\begin{array}{c}0.0299 \\
(0.0521)\end{array}$ & $\begin{array}{l}0.0334 \\
(0.0476)\end{array}$ \\
\hline \multirow[t]{2}{*}{ WAM-ENTRY } & $\begin{array}{l}\text { Weighted average of a dummy variable for whether entry } \\
\text { occurs in a bank's markets (averaged over the previous three } \\
\text { years), where the weights are the proportions of this bank's } \\
\text { deposits in each market. }\end{array}$ & $\begin{array}{c}0.1162 \\
(0.2572)\end{array}$ & $\begin{array}{l}0.2421 \\
(0.3306)\end{array}$ \\
\hline & Other Competitive Conditions in Bank’s Market(s) & & \\
\hline WAM-HERF & Weighted average of local market Herfindahl index. & $\begin{array}{c}0.2542 \\
(0.1614) \\
\end{array}$ & $\begin{array}{c}0.2000 \\
(0.1174) \\
\end{array}$ \\
\hline WAM-SHAREL & $\begin{array}{l}\text { Weighted average of shares of market deposits held by large } \\
\text { banks }(\text { GTA }>\$ 100 \mathrm{M}) \text {. }\end{array}$ & $\begin{array}{c}0.4772 \\
(0.3663) \\
\end{array}$ & $\begin{array}{c}0.8730 \\
(0.1388) \\
\end{array}$ \\
\hline WAM-SHAREC & $\begin{array}{l}\text { Weighted average of shares of market deposits held by } \\
\text { complex banks (owned by out-of-state or multilayer (BHC). }\end{array}$ & $\begin{array}{c}0.2513 \\
(0.2659) \\
\end{array}$ & $\begin{array}{c}0.3317 \\
(0.2538) \\
\end{array}$ \\
\hline BANK-INMSA & $\begin{array}{l}\text { Dummy variable indicating that bank is headquartered in an } \\
\text { MSA. }\end{array}$ & $\begin{array}{c}0.3273 \\
(0.4692) \\
\end{array}$ & $\begin{array}{c}0.6671 \\
(0.4712) \\
\end{array}$ \\
\hline \multirow[t]{2}{*}{ NEWLIB } & $\begin{array}{l}\text { Dummy variable, equals } 1 \text { if the state moved to a more liberal } \\
\text { branching rule this year. }\end{array}$ & $\begin{array}{c}0.0190 \\
(0.1364) \\
\end{array}$ & $\begin{array}{c}0.0200 \\
(0.1400)\end{array}$ \\
\hline & Demand Conditions in the Bank's Market(s) & & \\
\hline STINCGROW & Real state income growth & $\begin{array}{l}0.0396 \\
(0.0248)\end{array}$ & $\begin{array}{c}0.0392 \\
(0.0249)\end{array}$ \\
\hline WAM-GROW & Weighted average of growth rate of market deposits. & $\begin{array}{c}0.0134 \\
(0.1413) \\
\end{array}$ & $\begin{array}{r}0.0136) \\
(0.1504) \\
\end{array}$ \\
\hline WAM-PFRAT & $\begin{array}{l}\text { Weighted average of market average purchased funds/GTA } \\
\text { ratio. }\end{array}$ & $\begin{array}{l}0.1599 \\
(0.0786)\end{array}$ & $\begin{array}{l}0.2213 \\
(0.1051)\end{array}$ \\
\hline WAM-LNDEP & $\begin{array}{l}\text { Weighted average of market size (log of market deposits } \\
[\$ 000]) .\end{array}$ & $\begin{array}{l}13.2118 \\
(1.9434) \\
\end{array}$ & $\begin{array}{l}14.9084 \\
(1.9242) \\
\end{array}$ \\
\hline WAM-MDEP1 & Proportion of bank's deposits in metropolitan markets $\leq \$ 1 \mathrm{~B}$. & $\begin{array}{c}0.0222 \\
(0.1429)\end{array}$ & $\begin{array}{c}0.0342 \\
(0.1631)\end{array}$ \\
\hline WAM-MDEP2 & $\begin{array}{l}\text { Proportion of bank's deposits in metropolitan markets from } \\
\text { \$1B - \$5B. }\end{array}$ & $\begin{array}{r}0.11807 \\
(0.3165)\end{array}$ & $\begin{array}{c}0.2062 \\
(0.3731)\end{array}$ \\
\hline WAM-RDEP1 & Proportion of bank’s deposits in rural markets $\leq \$ 100 \mathrm{M}$ & 0.1593 & 0.0149 \\
\hline
\end{tabular}




\begin{tabular}{|c|c|c|c|}
\hline & & $(0.3584)$ & $(0.0718)$ \\
\hline WAM-RDEP2 & $\begin{array}{l}\text { Proportion of bank's deposits in rural markets } \$ 100 \mathrm{M}- \\
\$ 300 \mathrm{M} \text {. }\end{array}$ & $\begin{array}{l}0.3670 \\
(0.4717)\end{array}$ & $\begin{array}{r}0.1465) \\
(0.3144)\end{array}$ \\
\hline \multirow[t]{2}{*}{ WAM-RDEP3 } & $\begin{array}{l}\text { Proportion of bank's deposits in rural markets greater than } \\
\$ 300 \mathrm{M} \text {. }\end{array}$ & $\begin{array}{c}0.1658 \\
(0.3643)\end{array}$ & $\begin{array}{l}0.2103 \\
(0.3714)\end{array}$ \\
\hline & Prices in the Bank’s Market(s) & & \\
\hline WAM-P1 & $\begin{array}{l}\text { Weighted average of market average price of consumer loans } \\
\text { (installment and credit cards and related plans). }\end{array}$ & $\begin{array}{c}0.0917 \\
(0.0239)\end{array}$ & $\begin{array}{c}0.0972 \\
(0.0221)\end{array}$ \\
\hline WAM-P2 & $\begin{array}{l}\text { Weighted average of market average price of non-real estate } \\
\text { business loans (commercial and industrial loans, agricultural } \\
\text { loans, loans to depository institutions, etc.). }\end{array}$ & $\begin{array}{c}0.1006 \\
(0.0323)\end{array}$ & $\begin{array}{c}0.0931 \\
(0.0292)\end{array}$ \\
\hline WAM-P3 & Weighted average of market average price of real estate loans. & $\begin{array}{l}0.0769 \\
(0.0126)\end{array}$ & $\begin{array}{c}0.0766 \\
(0.0108)\end{array}$ \\
\hline WAM-P4 & $\begin{array}{l}\text { Weighted average of market average price of securities (all } \\
\text { non-loan financial assets). }\end{array}$ & $\begin{array}{c}0.0481 \\
(0.0079)\end{array}$ & $\begin{array}{c}0.0451 \\
(0.0082)\end{array}$ \\
\hline WAM-W1 & $\begin{array}{l}\text { Weighted average of market average price of purchased funds } \\
\text { (jumbo CDs, foreign deposits, federal funds purchased, all } \\
\text { other liabilities except core deposits). }\end{array}$ & $\begin{array}{l}0.0376 \\
(0.0087)\end{array}$ & $\begin{array}{c}0.0389 \\
(0.0086)\end{array}$ \\
\hline WAM-W2 & $\begin{array}{l}\text { Weighted average of market average price of core deposits } \\
\text { (domestic transactions accounts, time and savings). }\end{array}$ & $\begin{array}{l}0.0257 \\
(0.0078)\end{array}$ & $\begin{array}{l}0.0227 \\
(0.079\end{array}$ \\
\hline \multirow[t]{2}{*}{ WAM-W3 } & $\begin{array}{l}\text { Weighted average of market average price of labor (1000's of } \\
\text { constant } 1994 \text { dollars per employee). }\end{array}$ & $\begin{array}{l}33.6046 \\
(5.6703)\end{array}$ & $\begin{array}{l}36.0752 \\
(7.9998) \\
\end{array}$ \\
\hline & Condition of Banks in the Bank's Market(s) & & \\
\hline WAM-ROE & Weighted average of average ROE in markets. & $\begin{array}{l}0.1349 \\
(0.0431)\end{array}$ & $\begin{array}{c}0.1411 \\
(0.0491)\end{array}$ \\
\hline WAM-NPL & Market nonperforming loan ratio. & $\begin{array}{l}0.0259 \\
(0.0134)\end{array}$ & $\begin{array}{l}0.0266 \\
(0.0121)\end{array}$ \\
\hline WAM-EQRAT & Market average equity/GTA ratio. & $\begin{array}{l}0.0906 \\
(0.0173)\end{array}$ & $\begin{array}{c}0.0838 \\
(0.0123)\end{array}$ \\
\hline \multirow[t]{2}{*}{ WAM-EFFIC } & $\begin{array}{l}\text { Weighted average of market efficiency measure (the negative } \\
\text { of the market average residual from Fourier flexible cost } \\
\text { function). }\end{array}$ & $\begin{array}{l}-0.0066 \\
(0.0817)\end{array}$ & $\begin{array}{l}-0.0153 \\
(0.0784)\end{array}$ \\
\hline & Bank Age & & \\
\hline BANK-AGE & Bank's age, in years (not included in regressions). & $\begin{array}{l}62.6084 \\
(35.7602)\end{array}$ & $\begin{array}{l}66.5586 \\
(40.1716)\end{array}$ \\
\hline BANK-LNAGE & Log of bank's age. & $\begin{array}{l}3.8411 \\
(0.9672)\end{array}$ & $\begin{array}{l}3.9254 \\
(0.8906)\end{array}$ \\
\hline BANK-YOUNG & $\begin{array}{l}\text { Dummy variable, indicating a young bank, age } 1-5 \text { years } \\
\text { (banks younger than } 1 \text { year do not have the required lagged } \\
\text { values of the bank variables and are excluded from the lending } \\
\text { analysis). }\end{array}$ & $\begin{array}{l}0.0398 \\
(0.1955)\end{array}$ & $\begin{array}{c}0.0184 \\
(0.1344)\end{array}$ \\
\hline BANK-ADOLES & $\begin{array}{l}\text { Dummy variable, indicating an adolescent bank, age 6-20 } \\
\text { years. }\end{array}$ & $\begin{array}{c}0.1734 \\
(0.3786)\end{array}$ & $\begin{array}{c}0.1576 \\
(0.3643)\end{array}$ \\
\hline \multirow[t]{2}{*}{ BANK-MATURE } & Dummy variable, indicating an mature bank, age $20+$ years & $\begin{array}{c}0.7868 \\
(0.4096)\end{array}$ & $\begin{array}{c}0.8240 \\
(0.3808)\end{array}$ \\
\hline & Bank Mergers and Acquisitions (M\&As) & & \\
\hline BANK-MERGE & Dummy variable, indicating that bank survived a merger. & $\begin{array}{l}0.0219 \\
(0.1465)\end{array}$ & $\begin{array}{l}0.1721 \\
(0.3775)\end{array}$ \\
\hline BANK-ACQUIS & Dummy variable indicating that bank changed top-tier BHC & $\begin{array}{l}0.0597 \\
(0.2370)\end{array}$ & $\begin{array}{l}0.0749 \\
(0.2632)\end{array}$ \\
\hline
\end{tabular}




\begin{tabular}{|c|c|c|c|}
\hline & Bank Size & & \\
\hline BANK-GTA & $\begin{array}{l}\text { Gross total assets (\$000), in real } 1994 \text { terms, (not included in } \\
\text { regressions). }\end{array}$ & $\begin{array}{l}43,400.43 \\
(23,844.78)\end{array}$ & $\begin{array}{l}1,206,686 \\
(7,894,534)\end{array}$ \\
\hline BANK-LNGTA & Log of GTA. & $\begin{array}{l}10.4981 \\
(0.6454)\end{array}$ & $\begin{array}{l}12.5600 \\
(1.1315)\end{array}$ \\
\hline BANK-SZU10M & Dummy variable indicating GTA $\leq \$ 10 \mathrm{M}$. & $\begin{array}{c}0.0359 \\
(0.1859)\end{array}$ & - \\
\hline BANK-SZ10M25M & Dummy variable indicating $\$ 10 \mathrm{M}<$ GTA $\leq \$ 25 \mathrm{M}$. & $\begin{array}{l}0.2366 \\
(0.4250)\end{array}$ & - \\
\hline BANK-SZ25M50M & Dummy variable indicating $\$ 25 \mathrm{M}<$ GTA $\leq \$ 50 \mathrm{M}$. & $\begin{array}{l}0.3660 \\
(0.4817)\end{array}$ & - \\
\hline BANK-SZ50M100M & $\begin{array}{l}\text { Dummy variable indicating } \$ 50 \mathrm{M}<\mathrm{GTA} \leq \$ 100 \mathrm{M} \\
\text { (excluded from small bank regressions as base case). }\end{array}$ & $\begin{array}{c}0.3615 \\
(0.4804) \\
\end{array}$ & - \\
\hline BANK-SZ100M1B & Dummy variable indicating $\$ 100 \mathrm{M}<$ GTA $\leq \$ 1 \mathrm{~B}$. & - & $\begin{array}{c}0.8823 \\
(0.3223) \\
\end{array}$ \\
\hline BANK-SZ1B10B & Dummy variable indicating $\$ 1 \mathrm{~B}<\mathrm{GTA} \leq \$ 10 \mathrm{~B}$. & - & $\begin{array}{c}0.0981 \\
(0.2975) \\
\end{array}$ \\
\hline BANK-SZG10B & $\begin{array}{l}\text { Dummy variable indicating GTA > \$10B (excluded from } \\
\text { large bank regressions as base case). }\end{array}$ & - & $\begin{array}{c}0.0196 \\
(0.1387) \\
\end{array}$ \\
\hline \multirow[t]{2}{*}{ BANK-SHARE } & Weighted average of bank's shares of local market deposits & $\begin{array}{c}0.1521 \\
(0.1978) \\
\end{array}$ & $\begin{array}{c}0.1331 \\
(0.1730) \\
\end{array}$ \\
\hline & Bank Ownership Structure & & \\
\hline BANK-ONEBHC & $\begin{array}{l}\text { Dummy variable indicating that bank is member of a single- } \\
\text { bank BHC. }\end{array}$ & $\begin{array}{c}0.4742 \\
(0.4993) \\
\end{array}$ & $\begin{array}{c}0.4268 \\
(0.4953)\end{array}$ \\
\hline BANK-MBHC & $\begin{array}{l}\text { Dummy variable indicating that bank is member of a multi- } \\
\text { bank BHC. }\end{array}$ & $\begin{array}{c}0.2301 \\
(0.4209) \\
\end{array}$ & $\begin{array}{c}0.4270 \\
(0.4947) \\
\end{array}$ \\
\hline BANK-MUL_LAY & $\begin{array}{l}\text { Dummy variable indicating that bank is member of a multi- } \\
\text { layered BHC. }\end{array}$ & $\begin{array}{c}0.0715 \\
(0.2577) \\
\end{array}$ & $\begin{array}{c}0.1803 \\
(0.3844) \\
\end{array}$ \\
\hline \multirow[t]{2}{*}{ BANK-OUTST } & $\begin{array}{l}\text { Dummy variable indicating that bank is member of an out-of- } \\
\text { state BHC. }\end{array}$ & $\begin{array}{c}0.0373 \\
(0.1895) \\
\end{array}$ & $\begin{array}{c}0.1579 \\
(0.3647) \\
\end{array}$ \\
\hline & Bank Financial Condition & & \\
\hline BANK-ROE & Bank's return on equity. & $\begin{array}{r}0.1097 \\
(01095) \\
\end{array}$ & $\begin{array}{c}0.1312 \\
(0.1069) \\
\end{array}$ \\
\hline BANK-EQRAT & Bank’s equity/GTA ratio. & $\begin{array}{c}0.1007 \\
(0.0368) \\
\end{array}$ & $\begin{array}{c}0.0897 \\
(0.0320) \\
\end{array}$ \\
\hline \multirow[t]{2}{*}{ BANK-NPL } & Bank's nonperforming loan ratio. & $\begin{array}{c}0.0288 \\
(0.0272) \\
\end{array}$ & $\begin{array}{c}0.0265 \\
(0.0229) \\
\end{array}$ \\
\hline & Annual Dummy Variables & & \\
\hline D1993 & $\begin{array}{l}\text { Dummy variable for } 1993 \text { (excluded from regressions as base } \\
\text { case). }\end{array}$ & $\begin{array}{r}0.1959 \\
(0.3969) \\
\end{array}$ & $\begin{array}{c}0.1754 \\
(0.3803) \\
\end{array}$ \\
\hline D1994 & Dummy variable for 1994. & $\begin{array}{c}0.1855 \\
(0.3887) \\
\end{array}$ & $\begin{array}{c}0.1733 \\
(0.3786) \\
\end{array}$ \\
\hline D1995 & Dummy variable for 1995. & $\begin{array}{c}0.1733 \\
(0.3785) \\
\end{array}$ & $\begin{array}{c}0.1681 \\
(0.3740) \\
\end{array}$ \\
\hline D1996 & Dummy variable for 1996. & $\begin{array}{c}0.1602 \\
(0.3668) \\
\end{array}$ & $\begin{array}{c}0.1660 \\
(0.3721) \\
\end{array}$ \\
\hline D1997 & Dummy variable for 1997. & $\begin{array}{l}0.1496 \\
(0.3567)\end{array}$ & $\begin{array}{l}0.1636 \\
(0.3699)\end{array}$ \\
\hline D1998 & Dummy variable for 1998. & $\begin{array}{l}0.1355 \\
(0.3422)\end{array}$ & $\begin{array}{l}0.1536 \\
(0.3605)\end{array}$ \\
\hline
\end{tabular}


TABLE 2: Additional Summary Statistics on Four Important Exogenous Variables

Panel A: Mean, Range, and Quartiles

\begin{tabular}{|c|c|c|c|c|c|c|c|c|}
\hline & \multicolumn{4}{|c|}{ Small Banks } & \multicolumn{4}{|c|}{ Large Banks } \\
\hline & $\begin{array}{l}\text { WAM- } \\
\text { MERGE }\end{array}$ & $\begin{array}{l}\text { WAM- } \\
\text { ACQUIS }\end{array}$ & $\begin{array}{l}\text { WAM- } \\
\text { ENTRY }\end{array}$ & $\begin{array}{l}\text { GTA } \\
(\$ 000)\end{array}$ & $\begin{array}{l}\text { WAM- } \\
\text { MERGE }\end{array}$ & $\begin{array}{l}\text { WAM- } \\
\text { ACQUIS }\end{array}$ & $\begin{array}{l}\text { WAM- } \\
\text { ENTRY }\end{array}$ & $\begin{array}{l}\text { GTA } \\
\text { (\$000) }\end{array}$ \\
\hline Mean & 0.1148 & 0.0299 & 0.1162 & 43,400 & 0.1774 & 0.0334 & 0.2421 & $1,206,686$ \\
\hline Min & 0.0 & 0.0 & 0.0 & 982 & 0.0 & 0.0 & 0.0 & 100,015 \\
\hline $25 \%$ & 0.0 & 0.0 & 0.0 & 23,635 & 0.0764 & 0.0 & 0.0 & 132,343 \\
\hline $50 \%$ & 0.0785 & 0.0 & 0.0 & 39,297 & 0.1619 & 0.0112 & 0.0 & 196,496 \\
\hline $75 \%$ & 0.1879 & 0.0422 & 0.0 & 60,819 & 0.2546 & 0.0510 & 0.3333 & 391,122 \\
\hline $\operatorname{Max}$ & 0.7445 & 0.6667 & 1.0 & 99,953 & 0.7129 & 0.3749 & 1.0 & $278,391,391$ \\
\hline
\end{tabular}

Panel B: Year-by-Year Means and Standard Deviations

\begin{tabular}{|c|c|c|c|c|c|c|c|c|}
\hline & \multicolumn{4}{|c|}{ Small Banks } & \multicolumn{4}{|c|}{ Large Banks } \\
\hline & $\begin{array}{l}\text { WAM- } \\
\text { MERGE }\end{array}$ & $\begin{array}{l}\text { WAM- } \\
\text { ACQUIS }\end{array}$ & $\begin{array}{l}\text { WAM- } \\
\text { ENTRY }\end{array}$ & $\begin{array}{l}\text { GTA } \\
(\$ 000)\end{array}$ & $\begin{array}{l}\text { WAM- } \\
\text { MERGE }\end{array}$ & $\begin{array}{l}\text { WAM- } \\
\text { ACQUIS }\end{array}$ & $\begin{array}{l}\text { WAM- } \\
\text { ENTRY }\end{array}$ & $\begin{array}{l}\text { GTA } \\
(\$ 000)\end{array}$ \\
\hline 1993 & $\begin{array}{l}0.0788 \\
(0.0901)\end{array}$ & $\begin{array}{l}0.0295 \\
(0.0539)\end{array}$ & $\begin{array}{l}0.1478 \\
(0.2967)\end{array}$ & $\begin{array}{l}42,753 \\
(23,917)\end{array}$ & $\begin{array}{l}0.1263 \\
(0.0925)\end{array}$ & $\begin{array}{l}0.0339 \\
(0.0505)\end{array}$ & $\begin{array}{l}0.2781 \\
(0.3518)\end{array}$ & $\begin{array}{l}1,041,203 \\
(5,784,301)\end{array}$ \\
\hline 1994 & $\begin{array}{l}0.0909 \\
(0.1046)\end{array}$ & $\begin{array}{l}0.0310 \\
(0.0552)\end{array}$ & $\begin{array}{l}0.1210 \\
(0.2626)\end{array}$ & $\begin{array}{l}43,094 \\
(23,872)\end{array}$ & $\begin{array}{l}0.1407 \\
(0.1048)\end{array}$ & $\begin{array}{l}0.0350 \\
(0.0516)\end{array}$ & $\begin{array}{l}0.2345 \\
(0.3205)\end{array}$ & $\begin{array}{l}1,102,923 \\
(6,186,939)\end{array}$ \\
\hline 1995 & $\begin{array}{l}0.1186 \\
(0.1356)\end{array}$ & $\begin{array}{l}0.0323 \\
(0.0554)\end{array}$ & $\begin{array}{l}0.0951 \\
(0.2313)\end{array}$ & $\begin{array}{l}42,964 \\
(23,805)\end{array}$ & $\begin{array}{l}0.1695 \\
(0.1279)\end{array}$ & $\begin{array}{l}0.0345 \\
(0.0483)\end{array}$ & $\begin{array}{l}0.2040 \\
(0.3109)\end{array}$ & $\begin{array}{l}1,177,965 \\
(6,990,906)\end{array}$ \\
\hline 1996 & $\begin{array}{l}0.1320 \\
(0.1427)\end{array}$ & $\begin{array}{l}0.0302 \\
(0.0517)\end{array}$ & $\begin{array}{l}0.0919 \\
(0.2292)\end{array}$ & $\begin{array}{l}43,718 \\
(23,960)\end{array}$ & $\begin{array}{l}0.1877 \\
(0.1363)\end{array}$ & $\begin{array}{l}0.0363 \\
(0.0497)\end{array}$ & $\begin{array}{l}0.2131 \\
(0.3168)\end{array}$ & $\begin{array}{l}1,224,841 \\
(7,517,213)\end{array}$ \\
\hline 1997 & $\begin{array}{l}0.1383 \\
(0.1403)\end{array}$ & $\begin{array}{l}0.0317 \\
(0.0491)\end{array}$ & $\begin{array}{l}0.1081 \\
(0.2423)\end{array}$ & $\begin{array}{l}44,189 \\
(23,907)\end{array}$ & $\begin{array}{l}0.2089 \\
(0.1362)\end{array}$ & $\begin{array}{l}0.0357 \\
(0.0454)\end{array}$ & $\begin{array}{l}0.2400 \\
(0.3297)\end{array}$ & $\begin{array}{l}1,273,197 \\
(9,051,002)\end{array}$ \\
\hline 1998 & $\begin{array}{l}0.1485 \\
(0.1438)\end{array}$ & $\begin{array}{l}0.0235 \\
(0.0435)\end{array}$ & $\begin{array}{l}0.1284 \\
(0.2615)\end{array}$ & $\begin{array}{l}44,062 \\
(23,507)\end{array}$ & $\begin{array}{l}0.2412 \\
(0.1450)\end{array}$ & $\begin{array}{l}0.0241 \\
(0.0360)\end{array}$ & $\begin{array}{l}0.2848 \\
(0.3447)\end{array}$ & $\begin{array}{l}1,453,774 \\
(11,071,247)\end{array}$ \\
\hline
\end{tabular}


TABLE 3: SBL Lending Regressions for Banks of Various Sizes and Ages, 1993-1998

\begin{tabular}{|c|c|c|c|c|c|c|c|c|c|c|}
\hline & \multicolumn{2}{|c|}{ Small Banks } & \multicolumn{2}{|c|}{ Large Banks } & \multicolumn{2}{|c|}{ Sm. Bks.: Young } & \multicolumn{2}{|c|}{ Sm.Bks.: Adoles } & \multicolumn{2}{|c|}{ Sm. Bks.: Mature } \\
\hline & $\underline{\text { est. }}$ & $\underline{\text { t-stat. }}$ & $\underline{\text { est. }}$ & $\underline{\text { t-stat. }}$ & $\underline{\text { est. }}$ & $\underline{\text { t-stat. }}$ & $\underline{\text { est. }}$ & $\underline{\text { t-stat. }}$ & est. & $\underline{\text { t-stat. }}$ \\
\hline INTERCEPT & $-0.4858^{* *}$ & -2.132 & $2.9355^{* * *}$ & 13.342 & -0.1482 & -0.124 & 0.7469 & 1.322 & $-0.9627^{* * *}$ & -3.710 \\
\hline $\begin{array}{l}\text { Market M\&A and entry: } \\
\text { WAM-MERGE }\end{array}$ & $0.1772^{* * * *}$ & 5.050 & $0.1527^{* * *}$ & 3.179 & 0.0270 & 0156 & $01398^{*}$ & 1818 & $0.2661^{* * *}$ & 6.277 \\
\hline WAM-ACQUIS & -0.1083 & -1.506 & -0.0935 & -0.684 & 0.3202 & 0.934 & 0.0874 & 0.516 & $-0.1722^{* *}$ & -2073 \\
\hline WAM-ENTRY & $0.0660^{* * * *}$ & 3.353 & $-0.1139^{* * *}$ & -5.118 & 0.0153 & 0.210 & 0.0231 & 0.631 & $0.2062^{* * *}$ & 7.926 \\
\hline $\begin{array}{l}\text { Other competitive } \\
\text { conditions in market: }\end{array}$ & & & & & & & & & & \\
\hline WAM-HERF & $0.2252^{* * *}$ & 5.241 & $0.3851^{\text {**** }}$ & 4.854 & $0.6347^{* *}$ & 2.185 & 0.1272 & 1.145 & $0.2884^{* * * *}$ & 6.206 \\
\hline WAM-SHAREL & $-0.0409^{*}$ & -1.900 & $0.1592^{* *}$ & 2.269 & 0.2652 & 1.377 & $0.3891^{* * *}$ & 5.857 & $-0.0989^{* * *}$ & -4.415 \\
\hline WAM-SHAREC & $-0.0500^{* * *}$ & -3.210 & $-0.2613^{* * *}$ & -9.894 & -0.1067 & -1.420 & $-0.1133^{* * *}$ & -3.234 & -0.0269 & -1.422 \\
\hline BANK-INMSA & $-0.1284^{* * *}$ & -6.818 & $0.1500^{* * *}$ & 5.115 & -0.0324 & -0.314 & 0.0318 & 0.616 & $-0.1580^{* * *}$ & -7.813 \\
\hline NEWLIB & $-0.0682^{* * *}$ & -2.558 & $0.1350^{* * * *}$ & 3.278 & 0.0976 & 0.698 & -0.0004 & -0.005 & $-0.0726^{* * * *}$ & -2.623 \\
\hline $\begin{array}{l}\text { Demand conditions } \\
\underline{\text { in market: }}\end{array}$ & & & & & & & & & & \\
\hline STINCGROW & -0.0351 & -0.158 & $-0.8910^{* * * *}$ & -2.666 & -1.1982 & -0.895 & -0.8885 & -1.533 & $0.4572^{*}$ & 1.842 \\
\hline WAM-GROW & 0.0116 & 0.498 & -0.0189 & -0.474 & 0.1403 & 1.077 & -0.0723 & -1.552 & $0.0496^{*}$ & 1.760 \\
\hline WAM-PFRAT & $-0.2895^{* * *}$ & -4.550 & $-0.3993^{* * *}$ & -4.472 & $0.6015^{*}$ & 1.875 & 0.1704 & 1.064 & $-0.5275^{* * *}$ & -7.176 \\
\hline WAM-LNDEP & $0.0246^{* * *}$ & 3.107 & $0.0614^{* * *}$ & 5.577 & $0.0566^{*}$ & 1.684 & 0.0009 & 0.051 & 0.0067 & 0.681 \\
\hline WAM-MDEP1 & $0.1355^{* * *}$ & 4.342 & $0.2099^{* * *}$ & 4.234 & $0.3585^{* * *}$ & 2.741 & 0.0194 & 0.299 & $0.2000^{* * *}$ & 5.055 \\
\hline WAM-MDEP2 & $0.0633^{* * *}$ & 3.345 & $0.1547^{* * *}$ & 6.298 & $0.1207^{*}$ & 1.668 & -0.0117 & -0.307 & $0.1207^{* * *}$ & 4.794 \\
\hline WAM-RDEP1 & $-0.0908^{* *}$ & -2.099 & $0.5639^{* * *}$ & 4.710 & $-0.6450^{* *}$ & -2.333 & 0.0407 & 0.374 & -0.0727 & -1.396 \\
\hline WAM-RDEP2 & $-0.0869^{* *}$ & -2.365 & -0.0133 & -0.241 & $-0.3594^{* *}$ & -1.992 & -0.0530 & -0.628 & -0.0681 & -1.501 \\
\hline WAM-RDEP3 & -0.0504 & -1.579 & $-0.1367^{* * *}$ & 3.043 & -0.0819 & -0.597 & -0.0219 & -0.317 & -0.0166 & -0.415 \\
\hline Prices in market: & & & & & & & & & & \\
\hline$\overline{\text { WAM-P1 }}$ & $0.6667^{* * *}$ & 4.420 & $0.4598^{*}$ & 1.751 & 0.5085 & 0.546 & -0.2422 & -0.589 & $0.7800^{* * *}$ & 4.796 \\
\hline WAM-P2 & $-0.6262^{* * *}$ & -5.369 & $-2.7548^{* * *}$ & -11.051 & -0.8921 & -1.032 & $-0.6896^{* *}$ & -2.060 & $-0.3782^{* * *}$ & -3.072 \\
\hline WAM-P3 & $-1.3193^{* * *}$ & -4.237 & $-1.5239^{* *}$ & -2.500 & 3.7496 & 1.336 & -0.9958 & -1.175 & $-1.2400^{* * *}$ & -3.768 \\
\hline WAM-P4 & $-6.4327^{* * *}$ & -11.130 & $-6.5449^{* * *}$ & -7.502 & -2.1967 & -0.673 & $-6.6479^{* * *}$ & -4.665 & $-7.0906^{* * *}$ & -10.929 \\
\hline WAM-W1 & $1.5122^{* * *}$ & 2.747 & $4.0039^{* * *}$ & 4.586 & -4.2045 & -1.142 & $3.1703^{* *}$ & 2.147 & $1.4186^{* *}$ & 2.402 \\
\hline WAM-W2 & $-5.9331^{* * * *}$ & -9.071 & $-5.7912^{* * *}$ & -6.266 & $-9.1868^{* * *}$ & -2.833 & $-4.8807^{* * *}$ & -2.735 & $-5.752^{* * *}$ & -7.860 \\
\hline WAM-W3 & $0.0028^{* * *}$ & 3.705 & $-0.0131^{* * *}$ & -12.113 & -.0068 & -1.487 & $-0.0038^{*}$ & -1.845 & $0.0034^{* * *}$ & 3.970 \\
\hline
\end{tabular}


Condition of banks

WAM-ROE

WAM-NPL

WAM-EQRAT

WAM-EFFIC

Bank age:

BANK-LNAGE

BANK-ADOLES

BANK-MATURE

Bank M\&As:

BANK-MERGE

BANK-ACQUIS

Bank size and

market share:

BANK-LNGTA

BANK-SZU10M

BANK-SZ10M25M

BANK-SZ25M50M

BANK-SZ100M1B

BANK-SZ1B10B

BANK-SHARE

Bank ownership and

complexity:

BANK-ONEBHC

BANK-MBHC

BANK-MUL_LAY

BANK-OUTST

Bank financial

condition:

BANK-ROE

BANK-EQRAT

BANK-NPL
Small Banks

Param.

est. $\quad$ t-stat.

$\begin{array}{cr}0.2744^{* * *} & 3.144 \\ -0.2871 & -0.982 \\ -0.8072^{\text {**** }} & -3.092 \\ 0.0091 & 0.193\end{array}$

$-0.1351^{* * * *}-16.932$

$-0.0793^{* * * *}-4.394$

$-0.1391^{* * *}-5.117$

$-0.0149 \quad-0.754$

$0.0009-0.056$

$-0.0577^{* * *}-3.327$

$-0.2068^{* * *}-3.408$

$-0.1136^{* * *}-4.452$

$-0.0239^{*}-1.833$

$-$

$-0.2021^{* * *}-5.110$

$0.1233^{* * *} 14.316$

$0.0872^{* * *} \quad 7.801$

$-0.0307^{* *}-2.280$

$-0.0786^{* * *}-4.321$

0.0023

$0.0696 \quad-22.751$

Table 3 (continued)

Large Banks

Param.

est. $\quad \underline{\text { t-stat. }}$

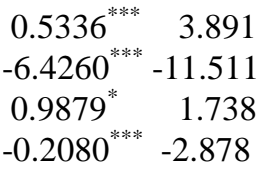

$-0.2080-2.878$

$0.0429 \quad 6.503$

-

$0.1582^{* * *} 13.276$

$0.0257 \quad 1.269$

$-0.3922^{* * *}-55.718$

$-$

$-0.4889^{* * *}-15.412$

$-0.1755^{\text {*** }}-9.832$

$-0.2547^{* * *}-5.353$

$0.0911^{* * *} \quad 3.979$

$0.0305 \quad 1.248$

$0.0479^{* * *} \quad 3.645$

$-0.0443^{* * *}-3.099$

$-0.0477-0.841$

$1.2211^{* * *} \quad 5.183$

$0.2375 \quad 0.851$
Sm. Bks.: Young

Param.

est. t-stat.

$-0.9505^{*}-1.761$

$-3.4919^{* *}-2.078$

$-1.7272-0.820$

$-0.2143-0.742$

$0.0068 \quad 0.107$

$-$

$0.0833 \quad 0.758$

$0.0672 \quad 0.459$

$-0.1690^{*}-1.805$

$-0.1020 \quad-0.273$

$\begin{array}{ll}-0.1077 & -0.839\end{array}$

$0.0402 \quad 0.635$

-

$1.5140^{* *} 2.399$

$0.0856^{* *} 2.126$

$-0.1893^{* * * *}-3.092$

$-0.0170 \quad-0.155$

$-0.1015 \quad-1.074$

$-0.3006^{* * *}-3.005$

$-1.4014^{\text {*** }}-2.772$

$-1.4784^{* *}-1.996$
Sm.Bks.: Adoles Param.

est. $\quad$ t-stat.

$0.2136 \quad 0.997$

$-0.5093-1.620$

$-1.9379^{* *}-2.428$

$0.1987^{*} \quad 1.707$

$-0.1738^{* * *}-7.097$

$$
\text { - }
$$

$-0.1622^{* *}-2.559$

$-0.0240 \quad-0.544$

$-0.1585^{\text {*** }}-3.606$

$-0.1760 \quad-0.937$

$-0.1234^{*}-1.891$

$-0.0456 \quad-1.423$

-

$\begin{array}{ll}-0.0128 & -0.089\end{array}$

$0.066^{\text {*** }} \quad 3.462$

$0.0179 \quad 0.618$

$-0.1053^{\text {*** }}-2.835$

$0.0299 \quad 0.688$

$-0.0505 \quad-0.884$

$-1.0468^{* * *}-3.240$

$-0.5093-1.620$
Sm. Bks. : Mature Param.

est. tstat.

$\begin{array}{cr}0.5536^{* * * *} & 5.689 \\ -0.9454^{* * *} & -3.004 \\ -0.1762 & -0.650 \\ -0.0067 & -0.125 \\ -0.1214^{* * *} & -14.443 \\ - & \\ - & \\ & \\ 0.0080 & 0.391 \\ 0.0155 & 0.862\end{array}$

$-0.0222-1.168$

$-0.1752^{* * *}-2.773$

$-0.1055^{\text {**** }}-3.783$

$-0.0288^{* *}-1.987$

$-0.3101^{\text {*** }}-7.505$

$0.1732^{* * *} 16.872$

$0.1370^{* * * *} 10.805$

$-0.0160 \quad-1.122$

$-0.1036^{* * *}-5.021$

$0.2453^{* * *} 4.485$

$-3.7213^{\text {*** }}-25.673$

$0.6906^{* * *} 4.161$ 


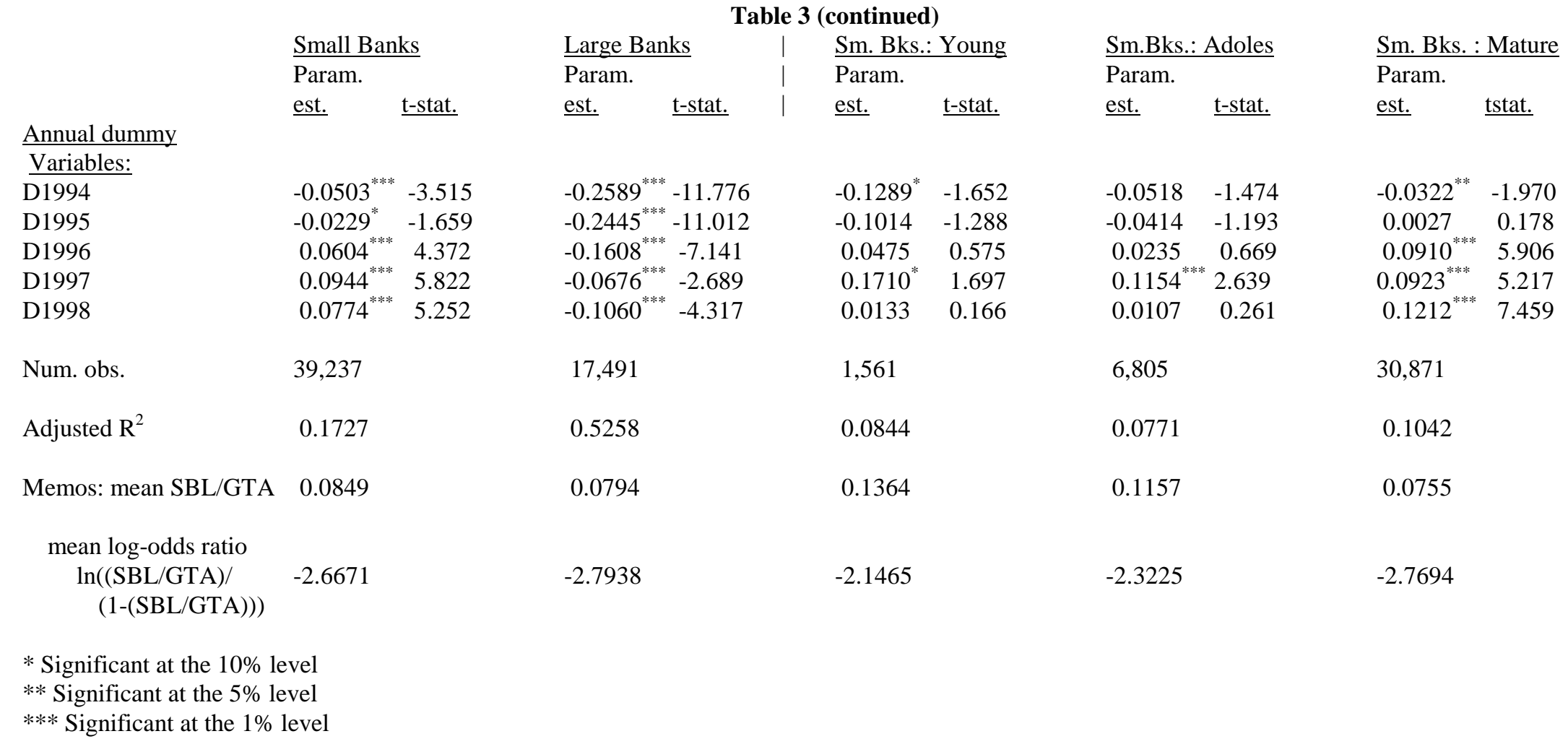

